\title{
Analisis Parameter Pertumbuhan Ayam Kedu Jengger Merah dan Jengger Hitam Generasi Ke-Dua di Balai Pembibitan dan Budidaya Ternak Non Ruminansia Satker Ayam Maron Kabupaten Temanggung
}

\section{Analysis of Growth Parameters of Second Generation Red Comb and Black Comb Kedu Chicken in Balai Pembibitan dan Budidaya Ternak Non Ruminansia Satker Ayam Maron Kabupaten Temanggung}

\author{
T. Arianto*, H. I. Wahyuni, dan E. Kurnianto \\ Fakultas Peternakan dan Pertanian Universitas Diponegoro, Kampus Tembalang, Semarang 50275 \\ *E-mail: tovika7@gmail.com \\ (Diterima: 1 Juni 2018; Disetujui: 13 November 2018)
}

\begin{abstract}
ABSTRAK
Penelitian bertujuan untuk menganalisis dan membandingkan peubah pertumbuhan antara Ayam Kedu jengger merah (AKJM) dan jengger hitam (AKJH) generasi ke-2 baik jantan maupun betina. Materi yang digunakan adalah Ayam Kedu generasi ke-2 (G2) yang baru menetas sebanyak 313 ekor, terdiri dari 154 ekor AKJH dan 159 ekor AKJM. Jumlah AKJH betina sebanyak 90 ekor dan jantan 64 ekor sedangkan AKJM betina sebanyak 83 ekor dan jantan 76 ekor. Data bobot badan setiap individu ayam diperoleh dari penimbangan 3 hari sekali sejak menetas sampai dengan umur 60 hari. Peubah pertumbuhan dianalisis dengan model Gompertz menggunakan paket program Statistical Analysis System v6.12. Peubah pertumbuhan yang telah diperoleh digunakan untuk menganalisis titik infleksi. Hasil penelitian menunjukkan bahwa persamaan non linier AKJH jantan yaitu $Y=1921,57 \exp \left(-4,14 \exp ^{-0,02 t}\right)$, betina $Y=1589,45 \exp \left(-3,88 \exp ^{-0,02 t}\right)$, AKJM jantan $Y=1880,71 \exp \left(-4,10 \exp ^{-0,02 t}\right)$, betina $Y=1480,52 \exp \left(-3,89 \mathrm{e}^{-0,02 t}\right)$. Bobot badan dan umur pada titik infleksi AKJH jantan 882,151 g dan 62,400 hari, AKJH betina 729,68 g dan 58,242 hari, dan AKJM jantan 863,391 $\mathrm{g}$ dan 60,639 hari, AKJM betina 679,677 g dan 57,917 hari.

Kata Kunci: ayam kedu, jengger hitam, jengger merah, model Gompertz, parameter pertumbuhan, titik infleksi

\section{ABSTRACT}

The purpose of this study was to analyze and to compare the growth parameters of second generation red comb and black comb kedu chicken both for male and female. The material used was the second generation of Kedu Chicken (G2) of 313 chicken, consisted of 154 chicken of black comb kedu chicken (AKJH) and 159 chicks of red comb kedu chicken (AKJM) day-old chick. AKJH consisted of 90 female chicken and 64 males chicken, while AKJM consisted of 83 female chicken and 76 male chicken. Body weight data of each individual chicken was obtained from weighing at 3 days period from hatching until 60 days. The growth parameters were analyzed by using the Gompertz model by Statistical Analysis System $v 6.12$ program. The growth parameters obtained were used to analyze the inflection point. The results showed that the non-linear equation of AKJH male was $Y=1921,57 \exp (-4,14 \exp -0,02 t)$, AKJH female was $Y=1589,45 \exp (-3,88 \exp -0,02 t)$, AKJM male was $Y=1880,71 \exp (-4,10 \exp -0,02 t)$, AKJM female was $Y=1480,52 \exp (-3,89 e-0,02 t)$. Body weight and age at the inflection point of AKJH male was $882.151 \mathrm{~g}$ and 62,400 days, AKJH females were 729.68 $\mathrm{g}$ and 58,242 days and AKJM male was 863,391 $\mathrm{g}$ and 60,639 days, AKJM female was 679,677 $g$ and 57.917 days.
\end{abstract}

Keywords: black comb, growth parameter, inflection point, kedu chicken, red comb 


\section{PENDAHULUAN}

Indonesia memiliki keanekaragaman hayati yang berlimpah, diantaranya adalah ayam, baik ayam asli Indonesia maupun ayam lokal lainnya yang telah lama beradaptasi di Indonesia. Ayam Kedu merupakan ayam lokal yang dinyatakan sebagai plasma nutfah Jawa Tengah karena memiliki keunggulan secara genetis yaitu pertumbuhan dan produksi telur yang tinggi dibandingkan dengan ayam lokal lainnya. Produksi telur ayam Kedu sebanyak 159 butir/tahun (Menteri Pertanian, 2012). Perkembangan plasma nutfah ayam Kedu masih kurang, mengingat populasi dan produktivitasnya yang juga kurang berkembang.

Penyediaan bibit ayam lokal saat ini masih terbatas dan masih dalam skala yang belum begitu luas. Bibit yang berkualitas didapat dari hasil seleksi, padahal keberhasilan dalam suatu usaha peternakan sangat bergantung pada mutu bibit yang digunakan.

Rendahnya kualitas atau mutu bibit yang tersedia disebabkan karena adanya persilangan beberapa strain ayam dengan cara yang salah sehingga memungkinkan terjadinya persilangan inbreeding yang dapat menurunkan produktivitas ayam sehingga berdampak pada kualitas bibit dan pada akhirnya berpengaruh pada populasi. Salah satu indikator penurunan produktivitas yaitu produksi telur yang diperoleh menurun dan tidak seragam. Hal ini dapat diatasi dengan melaksanakan suatu program pemurnian melalui seleksi.

Program seleksi merupakan salah satu cara guna meningkatkan produktivitas, populasi dan mutu ayam Kedu agar diperoleh kualitas yang unggul. Seleksi yang dilakukan secara terarah terhadap indukan, melalui tampilan bobot badan atau produksi telurnya diharapkan dapat meningkatkan kualitas ayam kampung khususnya ayam Kedu.

Ayam lokal seperti ayam Kedu dengan ciri khas dan potensi produksinya, mulai dilirik. Ayam lokal ini mempunyai ciri khas fenotipe dengan potensi genetik yang spesifik, dapat dikembangkan menjadi ayam ras lokal (Iskandar, 2006). Ayam Kedu memiliki beberapa jenis dilihat dari warna bulu dan jenggernya antara lain ayam Kedu dengan bulu hitam dan jengger yang berwarna merah atau bulu dan jenggernya sama-sama berwarna hitam. Ayam Kedu jengger hitam memiliki bobot tetas rata-rata $\pm 28,98$ gr, bobot badan pada umur 9 minggu $\pm 630,72 \mathrm{~g}$ bagi yang jantan sedangkan yang betina pada umur yang sama mempunyai bobot badan $\pm 553,62 \mathrm{~g}$ (Nataamijaya, 2008). Pengamatan parameter pertumbuhan pada Ayam Kedu jengger merah dan hitam perlu dilakukan untuk mengetahui adanya perbedaan pertumbuhan antara ayam Kedu jengger merah dan jengger hitam sampai umur 8 minggu.

Data bobot badan yang diperoleh selama pemeliharaan dapat digunakan untuk membuat kurva pertumbuhan. Beberapa model pertumbuhan banyak digunakan untuk menganalisis pertumbuhan beberapa jenis ternak seperti sapi, kambing, kelinci dan lain-lain. Model tersebut antara lain adalah model Gompertz, Richards, Logistik, Brody dan Von Bertalanffy yang merupakan model perhitungan matematis yang umumnya digunakan saat menentukan kurva pertumbuhan (Inounu et al., 2007). Analisis parameter pertumbuhan pada ayam broiler strain Lohmann pernah dilakukan oleh (Wayan dan Setiarini, 2010) menggunakan pendekatan model Gompertz dan Logistic bahwa pada ayam jantan dan betina saat berumur 19 dan 20 hari mengalami laju pertumbuhan yang paling pesat dengan bobot badan $939,63 \mathrm{~g}$ pada ayam jantan dan 806,96 g pada ayam betina.

Penelitian ini bertujuan untuk menganalisis dan membandingkan parameterparameter pertumbuhan Ayam Kedu jengger merah dan jengger hitam generasi ke-2 (G2) baik jantan maupun betina dengan model Gompertz. 


\section{MATERI DAN METODE}

Materi yang digunakan pada penelitian adalah Ayam Kedu generasi ke-2 (G2) sebanyak 313 ekor, terdiri dari 154 ekor ayam Kedu jengger hitam (AKJH) dan 159 ekor ayam Kedu jengger merah (AKJM). Jumlah AKJH betina sebanyak 90 ekor dan jantan sebanyak 64 ekor, sedangkan AKJM betina sebanyak 83 ekor dan jantan sebanyak 76 ekor. Semua ayam-ayam tersebut dipelihara sejak umur 1 sampai 60 hari.

Parameter yang diamati adalah bobot badan dengan melakukan penimbangan setiap 3 hari sekali mulai dari menetas sampai dengan umur 60 hari. Data yang diperoleh kemudian dianalisis sebagai berikut:

\section{Analisis parameter pertumbuhan}

Data rataan per periode pengukuran yang diperoleh digunakan untuk melakukan analisis parameter pertumbuhan untuk masingmasing jenis ayam Kedu baik jantan maupun betina yang dilakukan dengan menggunakan rumus model Gompertz menurut Blasco et al. (2003):

$$
\mathrm{Y}=\mathrm{A} \exp \left(-\mathrm{B} \exp ^{-\mathrm{kt}}\right)
$$

Keterangan:

$\mathrm{Y}=$ Bobot badan ternak pada waktu $\mathrm{t}$

$\mathrm{A}=$ Bobot dewasa tubuh (asimtot)

$\mathrm{B}=$ Parameter skala (nilai konstanta)

$\mathrm{k}=$ rataan laju pertumbuhan hingga ternak mencapai dewasa tubuh

$\mathrm{t}=$ satuan waktu (umur dalam hari)

\section{Titik infleksi}

Titik infleksi untuk menentukan pertambahan bobot badan tertinggi dan umur saat pencapaian pada waktu tertentu dihitung dengan menggunakan rumus Gompertz seperti yang dijelaskan oleh Kurnianto et al. (1997) yaitu sebagai berikut:

a. Bobot badan pada saat infleksi $(\mathrm{Yi})=\mathrm{e}^{-1} \mathrm{~A}$

b. Umur pada saat infleksi $(\mathrm{ti})=(\ln \mathrm{B}) / \mathrm{k}$

Keterangan:

$A=$ Bobot dewasa tubuh (asimtot)

$\mathrm{B}=$ Parameter skala (nilai konstanta)

$\mathrm{e}=$ Logaritma dasar $(2,178282)$

$\mathrm{k}=$ Rataan laju pertumbuhan hinggaternak mencapai dewasa tubuh

\section{HASIL DAN PEMBAHASAN}

\section{Model Persamaan Pertumbuhan Berdasarkan Gompertz}

Persamaan regresi dari model Gompertz untuk pertumbuhan AKJH dan AKJM disajikan pada Tabel 1. Bobot dewasa pada AKJH lebih besar dibandingkan dengan AKJM yaitu masing-masing sebesar 1921,57 g; 1589,45 g pada AKJH jantan dan betina, dan 1880,71 g dan 1480,52 g pada AKJM jantan dan betina dengan laju pertumbuhan yang sama pada kedua jenis ayam yaitu 0,02 . Bobot badan tersebut sesuai dengan bobot badan AKJH pada penelitian Nataamijaya (2008) bahwa bobot dewasa ayam Kedu hitam berkisar antara 1,4-2,0 kg untuk ayam Kedu jantan, sedangkan pada ayam Kedu hitam betina bobot dewasa berkisar antara 1,1-

Tabel 1. Persamaan regresi pertumbuhan model Gompertz pada Ayam Kedu Jengger Hitam (AKJH) dan Jengger Merah (AKJM) untuk masing-masing jenis kelamin

\begin{tabular}{ccc}
\hline Jengger & Jenis Kelamin & Persamaan Regresi \\
\hline \multirow{2}{*}{ AKJH } & Jantan & $\mathrm{Y}=1921,57 \exp \left(-4,14 \exp ^{(-0,02) t}\right)$ \\
& Betina & $\mathrm{Y}=1589,45 \exp \left(-3,88 \exp ^{(-0,02) t}\right)$ \\
\multirow{2}{*}{ AKJM } & Jantan & $\mathrm{Y}=1880,71 \exp \left(-4,10 \exp ^{(-0,02) t}\right)$ \\
& Betina & $\mathrm{Y}=1480,52 \exp \left(-3,89 \exp ^{(-0,02) t}\right)$ \\
\hline
\end{tabular}

Keterangan: $\mathrm{Y}=$ Ukuran tubuh ternak pada waktu $\mathrm{t}$

$\mathrm{t}=$ satuan waktu (umur dalam hari) 
Tabel 2. Bobot Dugaan dan Simpangan Ayam Kedu Jantan Jengger Hitam (AKJH) dan Jengger Merah (AKJM) Model Gompertz

\begin{tabular}{|c|c|c|c|c|c|c|}
\hline \multirow{2}{*}{$\begin{array}{l}\text { Umur } \\
\text { (hari) }\end{array}$} & \multicolumn{4}{|c|}{ AKJH } & \multicolumn{2}{|c|}{ AKJM } \\
\hline & BB Nyata & BB Dugaan & $\mathrm{S}$ & BB Nyata & BB Dugaan & $\mathrm{S}$ \\
\hline 0 & 30,06 & 30,34 & $-0,28$ & 29,30 & 30,99 & $-1,69$ \\
\hline 3 & 35,35 & 39,92 & $-4,57$ & 35,26 & 40,89 & $-5,63$ \\
\hline 6 & 43,56 & 51,57 & $-8,01$ & 43,92 & 52,94 & $-9,02$ \\
\hline 9 & 58,46 & 65,50 & $-7,04$ & 61,17 & 67,37 & $-6,20$ \\
\hline 12 & 76,95 & 81,90 & $-4,95$ & 80,89 & 84,34 & $-3,45$ \\
\hline 15 & 97,81 & 100,90 & $-3,09$ & 101,77 & 104,00 & $-2,23$ \\
\hline 18 & 122,29 & 122,60 & $-0,31$ & 125,39 & 126,44 & $-1,05$ \\
\hline 21 & 145,92 & 147,07 & $-1,15$ & 153,59 & 151,70 & 1,89 \\
\hline 24 & 178,09 & 174,30 & 3,79 & 184,50 & 179,80 & 4,70 \\
\hline 27 & 213,67 & 204,28 & 9,40 & 218,02 & 210,66 & 7,36 \\
\hline 30 & 248,42 & 236,90 & 11,52 & 252,06 & 244,20 & 7,86 \\
\hline 33 & 272,37 & 272,07 & 0,30 & 282,76 & 280,27 & 2,49 \\
\hline 36 & 327,59 & 309,60 & 17,99 & 336,85 & 318,70 & 18,15 \\
\hline 39 & 351,23 & 349,32 & 1,91 & 360,86 & 359,26 & 1,60 \\
\hline 42 & 386,46 & 391,00 & $-4,54$ & 399,90 & 401,72 & $-1,82$ \\
\hline 45 & 433,01 & 434,40 & $-1,39$ & 442,14 & 445,83 & $-3,69$ \\
\hline 48 & 467,18 & 479,27 & $-12,09$ & 475,02 & 491,31 & $-16,29$ \\
\hline 51 & 504,78 & 525,36 & $-20,58$ & 519,42 & 537,90 & $-18,48$ \\
\hline 54 & 558,23 & 572,39 & $-14,16$ & 573,09 & 585,31 & $-12,22$ \\
\hline 57 & 632,84 & 620,10 & 12,74 & 647,76 & 633,28 & 14,48 \\
\hline 60 & 682,51 & 668,25 & 14,26 & 693,98 & 681,55 & 12,43 \\
\hline Rata-rata & & & $-0,49$ & & & $-0,51$ \\
\hline
\end{tabular}

Keterangan: $\mathrm{S}=$ Simpangan antara bobot badan nyata dengan bobot badan dugaan

$1,4 \mathrm{~kg}$. Bobot badan dewasa yang diperoleh pada AKJM berbeda dengan pendapat Rukmana (2003) bahwa bobot badan AKJM jantan dewasa berkisar antara $3 \mathrm{~kg}-3,5 \mathrm{~kg}$, sedangkan betina $2 \mathrm{~kg}-2,5 \mathrm{~kg}$.

Bobot dewasa baik AKJH maupun AKJM jantan lebih besar dibandingkan betina. Bobot tersebut sesuai dengan penelitian Iskandar dan Susanti (2007) yang menggunakan ayam Pelung sebagai materi penelitiannya bahwa ayam Pelung jantan memiliki bobot badan yang lebih besar dibandingkan ayam betina. Yaitu masingmasing 4-5 kg pada ayam jantan dan 3-4 kg pada ayam betina. Kurnia (2011) menyatakan bahwa ternak jantan tumbuh lebih cepat dan lebih berat pada umur yang sama dibandingkan ternak betina.

\section{Pendugaan Bobot Badan Berdasarkan Model Gompertz}

\section{Jantan}

Data bobot dugaan dan simpangan AKJH dan AKJM jenis kelamin jantan disajikan pada Tabel 2. Bobot dugaan model Gompertz pada AKJH jantan mengalami overestimate pada umur 0-21 hari dan umur 42-54 hari, namun mengalami underestimate pada umur 24-39 hari dan umur 57-60 hari, sedangkan pada AKJM jantan mengalami overestimate pada umur 0-18 hari dan 42-54 hari, namun mengalami underestimate pada umur 21-39 hari dan umur 57-60 hari.

Bobot badan dugaan AKJH dan AKJM jantan pada akhir penimbangan berkisar antara $668,25 \mathrm{~g}-681,55 \mathrm{~g}$, bobot tersebut sesuai 
Tabel 3. Bobot Dugaan dan Simpangan Ayam Kedu Betina Jengger Hitam (AKJH) dan Jengger Merah (AKJM) Model Gompertz

\begin{tabular}{|c|c|c|c|c|c|c|}
\hline \multirow{2}{*}{$\begin{array}{l}\text { Umur } \\
\text { (hari) }\end{array}$} & \multicolumn{4}{|c|}{ AKJH } & \multicolumn{2}{|c|}{ AKJM } \\
\hline & BB Nyata & BB Dugaan & $\mathrm{S}$ & BB Nyata & BB Dugaan & $\mathrm{S}$ \\
\hline 0 & 30,70 & 32,57 & $-1,87$ & 29,39 & 30,01 & $-0,62$ \\
\hline 3 & 36,85 & 42,36 & $-5,51$ & 34,36 & 39,13 & $-4,77$ \\
\hline 6 & 45,53 & 54,11 & $-8,58$ & 42,00 & 50,11 & $-8,11$ \\
\hline 9 & 59,63 & 67,99 & $-8,36$ & 56,26 & 63,09 & $-6,83$ \\
\hline 12 & 79,38 & 84,12 & $-4,74$ & 73,65 & 78,21 & $-4,56$ \\
\hline 15 & 98,58 & 102,59 & $-4,01$ & 92,63 & 95,53 & $-2,90$ \\
\hline 18 & 122,71 & 123,45 & $-0,74$ & 113,87 & 115,12 & $-1,25$ \\
\hline 21 & 147,93 & 146,71 & 1,22 & 138,03 & 136,98 & 1,06 \\
\hline 24 & 179,00 & 172,33 & 6,67 & 166,19 & 161,06 & 5,13 \\
\hline 27 & 212,30 & 200,23 & 12,07 & 196,34 & 187,31 & 9,03 \\
\hline 30 & 247,22 & 230,31 & 16,91 & 226,75 & 215,60 & 11,15 \\
\hline 33 & 272,33 & 262,36 & 9,92 & 249,34 & 245,81 & 3,53 \\
\hline 36 & 301,78 & 296,36 & 5,42 & 290,04 & 277,76 & 12,28 \\
\hline 39 & 325,16 & 331,96 & $-6,80$ & 316,32 & 311,26 & 5,06 \\
\hline 42 & 365,70 & 369,01 & $-3,30$ & 345,59 & 346,11 & $-0,52$ \\
\hline 45 & 402,44 & 407,26 & $-4,82$ & 372,91 & 382,09 & $-9,18$ \\
\hline 48 & 433,51 & 446,50 & $-12,99$ & 403,62 & 418,98 & $-15,36$ \\
\hline 51 & 470,50 & 486,48 & $-15,98$ & 436,49 & 456,57 & $-20,07$ \\
\hline 54 & 517,14 & 526,99 & $-9,85$ & 487,91 & 494,62 & $-6,71$ \\
\hline 57 & 577,00 & 567,79 & 9,21 & 541,74 & 532,93 & 8,81 \\
\hline 60 & 624,03 & 608,67 & 15,36 & 586,73 & 571,31 & 15,42 \\
\hline & Rata-rata & & $-0,51$ & & & $-0,45$ \\
\hline
\end{tabular}

Keterangan: $\mathrm{S}=$ Simpangan antara bobot badan nyata dengan bobot badan dugaan

dengan bobot ayam Kedu pada penelitian Muryanto dan Subiharta (1989) yaitu sebesar $681,40 \mathrm{~g}$. Perbedaan bobot badan dapat dipengaruhi oleh beberapa faktor diantrannya yaitu faktor genetik dan lingkungan. Soeparno (1994) menyatakan bahwa pertumbuhan pada ternak dapat dipengaruhi oleh faktor genetik dan lingkungan. AKJH memiliki pertumbuhan yang relatif lebih lambat dikarenakan AKJH mempunyai genetik yang lebih murni dibandingkan AKJM. Johari (2009) menyatakan bahwa ayam Cemani didapat dari perkawinan yang memiliki hubungan kekerabatan yang dekat dari beberapa generasi dan diikuti dengan seleksi yang terarah pada ayam yang berwarna hitam.

\section{Betina}

Data bobot dugaan dan simpangan
AKJH dan AKJM betina disajikan pada Tabel 3. Bobot dugaan model Gompertz pada AKJH betina mengalami overestimate pada umur 0-18 hari dan umur 39-54 hari, namun mengalami underestimate pada umur 21-36 hari dan umur 57-60 hari, sedangkan pada AKJM betina mengalami overestimate pada umur 0-18 hari dan 42-54 hari, namun mengalami underestimate pada umur 21-39 hari dan umur 57-60 hari.

Pendugaan bobot tetas pada AKJH dan AKJM betina masing-masing yaitu $32,57 \mathrm{~g}$ dan 30,01 g. Nilai bobot tetas tersebut lebih besar dibandingkan dengan penelitian Fitra (2005) yang menggunakan ayam Kampung sebagai materi penelitiannya bahwa bobot tetas pada ayam Kampung sebesar 27,10g, sedangkan berat tetas ayam Kedu pada 
Tabel 4. Bobot Infleksi dan Waktu Infleksi Pertumbuhan AKJH dan AKJM Jantan dan Betina Model Gompertz

\begin{tabular}{lcc}
\hline \multirow{2}{*}{ Jenis Kelamin } & \multicolumn{2}{c}{ Gompertz } \\
\cline { 2 - 3 } & Yi (g) & ti (hari) \\
\hline AKJH & & \\
Jantan & 882,151 & 62,400 \\
Betina & 729,680 & 58,242 \\
AKJM & & \\
Jantan & 863,391 & 60,639 \\
Betina & 679,677 & 57,917 \\
\hline
\end{tabular}

Keterangan: $\mathrm{Yi}=$ Bobot badan pada saat Infleksi

$$
\mathrm{ti}=\text { Umur pada saat Infleksi }
$$

penelitian Johari (2009) berkisar antara 19,2g sampai 37,3g. Hasil bobot tetas pada ayam Kedu dari beberapa penelitian tersebut sangat bervariasi.

Dugaan bobot badan saat menetas sampai dengan umur 60 hari pada AKJH berkisar antara 30,34g $-668,25 \mathrm{~g}$, pada AKJM berkisar antara 30,99g - 681,55g. Dugaan bobot badan tersebut lebih besar dibandingkan penelitian Nataamijaya (2008) bahwa pada umur yang sama bobot badan ayam Kedu berkisar antara 28,98g - 578,08g. Perbedaan pertumbuhan tersebut dapat dipengaruhi oleh beberapa faktor diantarannya dalah faktor lingkungan dan faktor genetik. Soeparno (1994) menyatakan bahwa pertumbuhan pada ternak dapat dipengaruhi oleh faktor genetik dan lingkungan.

\section{Titik Infleksi AKJH dan AKJM}

Data bobot infleksi dan umur waktu infleksi AKJH dan AKJM pada jenis kelamin jantan dan betina model Gompertz disajikan pada Tabel 4. Titik infleksi merupakan gambaran pada ternak bahwa ternak mulai mengalami masa pubertas dimana pertambahan bobot badan mencapai terbesar terjadi pada titik tertinggi dan setelah itu akan mulai menurun. Tazkia dan Anggraeni (2009) menyatakan bahwa titik infleksi adalah titik balik pada saat ternak mencapai umur pubertas, laju pertumbuhan ternak akan mulai melambat setelah pubertas atau dengan kata lain laju pertumbuhan akan melambat setelah melewati titik infleksi. Titik Infleksi AKJM

$(60,639$ hari dan 57,917 hari) pada jenis kelamin jantan dan betina terjadi lebih cepat dibandingkan AKJH (62,400 hari dan 58,242 hari). Hasil titik infleksi tersebut terjadi lebih lama dibandingkan dengan penelitian yang dilakukan oleh Wayan dan Setiarini (2010) yang menggunakan ayam Broiler sebagai materi penelitiannya bahwa pada ayam broiler betina titik infleksi terjadi pada umur 19,73 hari dengan bobot badan $806,96 \mathrm{~g}$, sedangkan pada ayam broiler jantan pada umur 19,38 hari dengan bobot badan 939,63g.

Bobot badan infleksi pada jenis kelamin jantan lebih besar dibandingkan betina baik pada AKJH dan AKJM. Jenis kelamin merupakan salah satu faktor yang mempengaruhi pertumbuhan. Hal tersebut sesuai dengan pendapat Kurnia (2011) yang menyatakan bahwa salah satu faktor yang mempengaruhi pertumbuhan adalah jenis kelamin karena ternak jantan biasanya tumbuh lebih cepat dan lebih berat pada umur yang sama dibandingkan ternak betina. Kristian (2005) melaporkan bahwa ternak jantan memiliki bobot badan yang lebih besar dibandingkan dengan betina pada ayam Pelung dan Bangkok.

\section{Koefisien Determinan $\left(\mathrm{R}^{2}\right)$ dan AIC (Akaike Information Criterion)}

Koefisien determinasi dan AIC dari model Gompertz untuk pertumbuhan AKJH dan AKJM berdasarkan analisis model pertumbuhan disajikan pada Tabel 5 . Koefisien Determinasi $\left(\mathrm{R}^{2}\right)$ dan AIC (Akaike 
Tabel 5. Koefisien Determinasi dan AIC Ayam Kedu Jengger Hitam dan Jengger Merah Pada Model Gompertz

\begin{tabular}{lcccc}
\hline \multirow{2}{*}{ Jenis Kelamin } & \multicolumn{3}{c}{$\left(\mathrm{R}^{2}\right)$} & \multicolumn{2}{c}{ (AIC) } \\
\cline { 2 - 5 } Jantan & AKJH & AKJM & AKJH & AKJM \\
Betina & 0.999 & 0.999 & 100.507 & 99.345 \\
\hline
\end{tabular}

Keterangan: R2 $=$ Koefisien Determinasi

$\mathrm{AIC}=$ Akaike Information Criterion

Information Criterion) merupakan tolok ukur kebaikan suatu model dimana semakin kecil nilai AIC dan semakin mendekati $100 \%$ pada nilai Koefisien determinan maka model tersebut semakin baik dan juga sebaliknya. Nilai AIC berdasarkan analisi model pertumbuhan Gompertz pada AKJH jantan dan betina masing-masing sebesar 100,507 dan 98,810, sedangkan pada AKJM jantan dan betina sebesar 99,345 dan 97,930. Nilai AIC pada AKJM lebih kecil dari pada AKJH, artinya jika dibandingkan antar jenis jengger maka model Gompertz lebih baik digunakan untuk menduga pertumbuhan AKJM dari pada AKJH. Jika dibandingkan dalam suatu jengger antara jantan dan betina pada AKJH model Gompertz lebih baik digunakan untuk menduga pertumbuhan pada jenis kelamin betina, sama halnya pada AKJM. Kutner et al. (2004) menyatakan bahwa AIC (Akaike's Information Criterion) merupakan suatu tolok ukur untuk menggambarkan kebaikan suatu model, dimana semakin kecil nilai AIC maka semakin baik model yang digunakan.

Nilai Koefisien Determinan pada AKJH dan AKJM memiliki nilai yang sama yaitu 0,999. Nilai tersebut mendekati 100\% artinya nilai Koefisien Determinan pada AKJH dan AKJM sama baiknya. Hal tersebut sesuai dengan pendapat Anindita et al. (2014) bahwa nilai koefisien determinan yang semakin mendekati 100\% merupakan hasil yang semakin baik.

\section{KESIMPULAN}

Bobot dewasa pada AKJH lebih besar dari pada AKJM baik pada jenis kelamin jantan dan betina. Titik Infleksi pada AKJM lebih cepat dicapai daripada AKJH pada kedua jenis kelamin, namun sebaliknya bobot badan infleksi pada AKJH lebih besar dibandingkan AKJM.

\section{DAFTAR PUSTAKA}

Anindita, A., N.W, S. Wardhani dan H. Kusdarwati. 2014. Pemilihan model stannard dan Richards pada pertumbuhan bobot itik. J. Mahasiswa Statistik. 2 (6): 473-476.

Blasco, A., M. Piles and L. Varona. 2003. A Bayesian analysis of the effect of selection for growth rate on growth curves in rabbits. Genet. Sel. Evol. $35: 21-41$.

Fitra, A.P. 2005. Beberapa kriteria analisis penduga bobot tetas dan bobot hidup umur 12 minggu dalam seleksi ayam kampung. JITV. 10 (4): 281-285

Inounu, I., D. Mauluddin, R. R. Noor dan Subandriyo. 2007. Analisis kurva pertumbuhan domba garut dan persilangannya. JITV. 12 (4): 286-299.

Iskandar, S. 2006. Strategi pengembangan ayam lokal. Wartazoa 16 (4): 190-197.

Iskandar, S dan T. Susanti. 2007. Karakter dan manfaat ayam Pelung di Indonesia. Wartazoa. 17 (3): 128-136.

Johari, S. 2009. Aplikasi Pemuliabiakan Pada Unggas. Badan Penerbit Universitas Diponegoro, Semarang.

Kristian. 2005. Perbandingan size dan shape tubuh ayam Pelung dan ayam Bangkok berdasarkan analisis komponen utama. Skripsi. Fakultas Peternakan. Institut 
Pertanian Bogor, Bogor.

Kurnia, Y. 2011. Morfometrik Ayam Sentul, Kampung dan Kedu Pada Fase Pertumbuhan Dari Umur 1 - 12 Minggu. Fakultas Peternakan, Institut Pertanian Bogor, Bogor. Skripsi.

Kurnianto, E., A. Shinjo dan D. Suga. 1997. Comparison of the three growth curve models for describing the growth patterns in wild and laboratory mice. J. Vet. Epidemiol. 1(2):49-55.

Kutner, M.H., Nachtsheim, C.J., Neter J. dan Li W. 2004, Applied Linier Statistical Models, Fifth Edition, McGraw Hill, New York.

Menteri Pertanian. 2012. Keputusan Menteri Pertanian No. 2487/Kpts/ LB.430/8/2012 tentang Penetapan Rumpun Ayam Kedu.

Muryanto dan Subiharta. 1989. Pertumbuhan dan produksi telur ayam Kedu hitam yang dipelihara secara intensif. Pros. Seminar Hasil-hasil Penelitian. Fakultas
Peternakan U.G.M. Yogyakarta.

Nataamijaya, A.G. 2008. Karakteristik dan produktivitas ayam Kedu hitam. Buletin Plasma Nutfah. 14 (2) : 85-89.

Rukmana, H.R. 2003. Ayam Buras. Kanisius IKAPI, Yogyakarta.

Soeparno. 1994. Ilmu dan Teknologi Daging. Cetakan Pertama. Gadjah Mada University Press, Yogyakarta.

Tazkia, R. dan A. Anggraeni. 2009. Pola dan Estimasi Kurva Pertumbuhan Sapi Friesian Holstein di Wilayah Kerja Bagian Timur KPSBU Lembang. Seminar Nasional Teknologi Peternakan dan Veteriner, 13-14 Agustus 2009. Hal 121-135.

Wayan, S.W. dan E.P.F. Setiarini. 2010. Menduga pertumbuhan bobot badan ayam broiler strain Lohmann dengan pendekatan model Logistic dan Gompertz. Veterinaria Medika. 3 (2): 105-108. 